\title{
Assessments of Modal Split in Long-distance Passenger Transport ${ }^{1}$
}

\section{Jakub Chmelík ${ }^{2}$}

\begin{abstract}
The goal of this paper is to present basic alternative assessments of the division of transport work (or also "modal split") of main transport modes. For this, an example of selected long-distance connections between centres in Czechia, including an identification of major underlying factors, shall be exploited. The paper examines the competitiveness of rail transport in its relation to bus and individual automobile transport, and relations with a potential of rail transport are primarily selected. A logit model is applied within the selected set of relations. It is entered in particular by indicators of time (time of a ride, frequency of public transport lines) and finances (actual transport costs) through a financial expression of generalised costs. The purpose of the paper is to verify the selected procedure on the relations transport modes of which are similar, and to highlight the alternatives of a comprehensive assessment of the modal split of main transport modes in Czechia. In the conclusion, the gained results are used to outline further alternative prospects of the topic under observation.
\end{abstract}

Key words: transport modes, modal split, competitiveness of rail, transport accessibility, generalized costs

JEL Classification: C25, O18, R41

\section{Introduction}

The topic of identifying the division of transport work (or also "modal split") and the factors underlying the choice of the actual means of transport have been a major research theme of the scientific disciplines examining the questions of transport in the long run. The demand for a study of the topic mentioned above is primarily caused by generally low consciousness of the share of individual transport modes in the modal split in a given relation that is mostly influenced by the usual ignorance of direction orientation of individual automobile transport as the main bearer of transport interactions. The absence of the necessary data has also a considerable impact on solution to

\footnotetext{
${ }^{1}$ This contribution was prepared thanks to research project number P404/12/1035 Spatial Dynamics of Transport Relationship in Settlement System of Czechia granted by Grant Agency of the Czech Republic. Author would like to thank Miroslav Marada and Viktor Květoň for valuable comments at the beginning of the study. Author also thank two anonymous reviewers for their helpful remarks and suggestions.

${ }^{2}$ Charles University in Prague, Faculty of Science, Department of Social Geography and Regional Development, Transport Geography Research Centre, Albertov 6, 12843 Praha 2, Czech Republic; jakub.chmelik@natur.cuni.cz
} 
practical tasks, especially in the sphere of strategy of the planning of offer of public transport as well as the planning of the influence of new transport infrastructure on modal split. In the conditions valid in Czechia, the urgent problem of identifying the real share of individual transport modes or individual carriers operating within the same relation or section in the modal split is associated with the questions of competition on the market in passenger transport within the economic competition policy. This involves specific tasks such as finding a suitable methodological mechanism for delineation of a relevant market (Kvizda 2011; Kvizda, Rederer 2012).

Competitiveness of individual transport modes within the modal split is influenced by a number of factors that are associated to a great extent with real spatial links of the centres arising from the geographic and transport position of a centre in the networks of individual transport modes (Marada 2006). They are closely connected to the character of settlement and the size of centres on the side of demand for transport, and with the level of public transport and transport infrastructure on the side of offer. In general, the factors influencing the choice of the mode with an impact on modal split can be divided into three groups (Ortúzar, Willumsen 2001; a similar division also e.g. Strandling, Anable 2008). The first group is constituted by a set of characteristics of the actor (passenger) that mainly include access to a car, driving license, marital status (for example, it can be presumed that the use of a car is influenced by the number of members of a household), income and type of employment (such as the possibility to use a company car) and, last but not least, the characteristics of the actor's place of residence (population density, urban versus rural area, transport position, etc.). The second group includes factors that influence the journey itself, when the choice of the mode is influenced by its purpose (such as the difference in the use of the means of transport for commuting to work or for a weekend trip journey, more e.g. Sheppard 1995) and the time when it occurs (such as a low offer of public transport in night hours, etc.). The third group of the underlying factors contains the characteristics of transport offer or transport opportunities for the population that can be divided into two categories: Quantitative and qualitative factors. The main quantitative factors that can be assessed rather well are as follows: The travel time (the time spent in a means of transport including walking, waiting at the stop, change, etc.), the price of transport (fare, fuel price, fixed operating costs, etc.) and, possibly, also the accessibility (and price) of parking. On the other hand, it is difficult to quantify qualitative factors that are often the most important circumstances influencing the choice of a means of transport. They can be in discrepancy with an economically rational choice. These "soft" factors primarily include comfort, conveniences, reliability, safety, etc. (for more see Ortúzar, Willumsen 2001).

The topic of assessment of regional differences in the distribution of modal split has only been examined marginally in Czech and Slovak surveys, primarily within a routine assessment of changes in the relation of spatial organisation of society and transport links. In the past decade, the attention has mainly been paid to studies evaluating the transport importance of centres on the basis of offer by public transport (e.g. Marada et al. 2010; Marada, Květoň 2010) or of road traffic volume (e.g. Kraft, Vančura 2009a), the competitiveness of individual modes on the basis of time accessibility (e.g. Kraft, Vančura 2009b; Seidenglanz 2009; Więckowski, Michniak et al. 2012; Horňák et al. 2013; Marada et al. 2014) or a combination of the above indicators along with theoretical intensities of interaction of centres (Chmelík et al. 2010; Horňák, Pšenka 2013). 
Specific case of change of modal split was focused on the study by Kvizda and Seidenglanz (2014). They analysed short-term intermodal shift from air to railway transport after Iceland's volcano eruption in April 2010. The described studies are mainly based on traditional research approaches in transport arising from quantitative and predictive methods. They are often criticized due to their considerable generalization of real social processes and motivation of individuals whose behaviour is considered absolutely rational in these approaches (such as the choice of the shortest route). This focus is based on the interdisciplinary nature of the study of transport. In it, an increasing role is played by experts with a technical rather than social background (Hanson 2006), which is also influenced by a shortage of "soft" theoretical approaches in transport as well as transport geography itself (Goetz et al. 2004: quoted in Goetz et al. 2009). The existing approaches in transport were challenged by a group of researchers (primarily sociologists) associated within the "new mobilities paradigm" (in particular Sheller, Urry 2006, with further discussions by Shaw et al. 2008; Keeling 2008). Their attention is paid to the effort to clarify and understand the motivation of journeys and real human mobility as well as the interest in emotional and symbolic components of transport behaviour (Brůhová-Foltýnová et al. 2008) with the use of qualitative research methods. This type of research that is primarily of sociological nature widens the discussion regarding the factors underlying transport behaviour and motivation of the choice of a means of transport (Strandling, Anable 2008). They often have a specific focus, examining the sex, age, social status, subjective perception of feelings during a journey, etc. In Czechia, the research of sociology of mobility, transport behaviour and the choice of the means of transport was conducted by Brůhová-Foltýnová et al. (2008) and Braun-Kohlová (2010), while the issues of daily mobility and day-to-day life were dealt with by Temelová et al. (2011) and by Mulíček et al. (2013).

The presented contribution loosely follows up on a previous study (Chmelík et al. 2010) that assessed the intensities of relations between Czechia's regional towns (i.e. a set of 78 relations) and the use of passenger rail transport, evaluated by means of three indicators: Offer of connections, the real demand, and modelled/theoretical interactions. The results revealed some interdependencies of the above-mentioned indicators for the individual relations, on the basis of which it was possible to identify a theoretical potential of railway transport towards other modes. The more this was true when looked at from the viewpoint of the relation of real demand (using the offer of rail lines) and model interactions that characterised the intensity of theoretical links of the centres. ${ }^{3}$ All of this was established without any deeper analysis of the modal split in a given relation or without inclusion of rival modes, bearing in mind the fact that the gained results are influenced by the initial set of relations with considerably differentiated structures.

The goal of the presented paper is to present basic alternative assessments of the modal split of main transport modes. One of the chief methods will be applied on the example of selected long-distance connections of centres in Czechia. At first, the basic alterna-

\footnotetext{
${ }^{3}$ The basic form of a gravitation model was applied in which the distance between centres was characterised by time accessibility on railway and the mass of centres by simple population number.
} 
tives to evaluate the modal split will be examined, especially in the sphere of the database available in Czechia, and a comparison to situation in Western-European countries will be made. On the basis of a discussion, a technique will be chosen to evaluate the share of main transport modes (individual automobile transport and public transport: Passenger railway transport and regular bus transport) for each specific relation. In accordance with a previous study (Chmelík et al. 2010) and the latest development on the transport market, the choice will be concentrated on relations with the presumption of a change in the potential of passenger rail transport. There will be a partial objective of identifying specific factors underlying the modal split. On account of the availability of the real data on modal split (see later text), the division of transport work will be observed in 2001, 2006, and 2011. In the conclusion, the values predicted by the model for 2011 (calibrated by the data from 2001, CSO 2003) will be compared to the real results of intensity of commuting by the mode from the 2011 Population and Housing Census (CSO 2013). This enables us to carry out a general assessment of whether the model can be used for the pursued objective. In connection with general trends in transport, one can presume in this interval an increasing share of individual automobile transport in the total modal split, with a slower pace in the relations with a quality public transport system. One can also presume that public transport will have the highest share in the relations situated along rail corridors and possibly also along motorways that provide an appropriate offer of lines. On the contrary, the lowest share can be expected in the relations with a lower offer of public transport (frequency, necessity to change), also determined by the quality of transport infrastructure. There is a similar situation in the case of identifying the share of modal split of railway and bus transport within the framework of public transport. In this sphere, one can presume a growing role of the railway in the relations linked by quality infrastructure in connection with a gradual modernisation of main lines and an extension of the offer of long-distance passenger railway transport in Czechia roughly from 2005 onwards. On the other hand, growing proportion of bus lines within the modal split of public transport can be presumed in relations with insufficient connection to the rail network. When it comes to the factors influencing the choice of the means of transport, in general it can be assumed that unlike the lower order levels, the role of the size of a centre that influences the level of transport opportunities for the population will not be an underlying factor in the sphere of long-distance rail links between Czechia's most important agglomerations. On the contrary, a major influence of transport location in the networks can be expected. The results themselves are followed up by the conclusion of the paper. Along with a summary of the main results and confirmation/refutation of research assumptions, the conclusion will include a critical assessment of the method used, including identification of the main problems and a proposal of their alternative solutions in possible subsequent research.

\section{Alternative Assessments of Modal Split}

In conditions of the Czech Republic, the basic assessment of modal split is rather limited by the available database. In general, the data from transport yearbooks (Transport Yearbook of the Czech Republic; Ministry of Transport 2013a; Transport Yearbook of Prague; TSK 2013, etc.) are primarily available each year. Based on the mandatory statistical enquiry ordered by the Transport Ministry, and on the surveys it conducts, the 
yearbooks present values of transport output of individual modes in passenger transport. However, neither there are any detailed data on directions, nor any additional information (the purpose of a journey, etc.). Besides, it is not sufficiently evident in which way the values were collected, especially in the cases in which it is said that this is an expert estimate (such as output of individual automobile transport in the Transport Yearbook of the Czech Republic). Due to this, results of the Population and Housing Census (CSO 2003 and 2013) are the only comprehensive source of information on the share of individual modes in the modal split in Czechia. Among others, the Census records the data on the means of transport used for commuting to work and schools down to the level of Czechia's individual municipalities, which is an undeniable advantage. However, the use of the data is also burdened with a number of problems. Above all, there is an absence of a continual time series arising from a ten-year period of observation and of additional time needed to process the results. Particularly in the intercensal period it is necessary to be cautious when dealing with the information. This is caused by a considerable dynamics of changes in day-to-day mobility of persons, in the offer of public transport and transport infrastructure as well as changes in the transport market in some relations. Moreover, there is one significant defect: Limited time differentiation of the frequency of commuting. In the routinely available results, it is only presented as daily and non-daily (total). Besides that, it can be presumed that a part of the results was affected by a wrong or incomplete or deliberately false filling of census sheets. The issue of the incomplete data is noticeable mainly in the results of commuting flows from the 2011 census (CSO 2013), where the number of the captured data states just 1.5 million commuters against more than 2.3 million in 2001 (CSO 2003). From the viewpoint of the study of the modal split, there is the associated problem of the publication of the results by the Czech Statistical Office, as commuting is presented differently in the commonly accessible outputs of the two latest censuses. The 2001 census (CSO, 2003) only published commuting by transport modes in connection to movement of manpower. The results from the 2011 census (CSO 2013) also include modal distribution by commuting to schools. This means that the differences eventually reduce the data set that can be used for a comparison of both censuses. Obviously, the data that also contain commuting to schools will differ in a number of relations, given the assumption of a much higher share of the use of public transport in the case of this target group. The use of the data from the censuses for comparison of the intervals mentioned above is also affected by the fact that commuting was recorded from the place of usual residence in 2011, but from the place of permanent residence in 2001. This change in the census method has resulted in an apparent decrease in recorded direction of commuting flows between centres in Czechia, which has the biggest impact just on longdistance relations typical of non-daily (weekly) commuting. In connection with commuting flows, also necessary is a discussion on the relevance of these data that inherently only record regular movements within the journeys to work or school. However, a number of other movements with a different motivation as far as the journey is concerned is not recorded (shopping trips, visits to friends, outdoor and holiday trips). For- 
eign surveys ${ }^{4}$ have revealed that the share of the journeys to work and to school accounts for roughly $30 \%$ of the total mobility expressed by passenger-kilometres. On the other hand, regular journeys (commuting and business trips) are usually the main purpose in long-distance mobility. Travel behaviour in commuting journeys is also more stable and homogenous than in case of others purposes (mainly leisure purposes journeys and visits to relatives and friends) (Hubert, Potier 2003). The surveys of transport behaviour which are conducted mainly in Western-European countries can serve to some degree to widening of the database about the modal split because one of the main spheres of interest is constituted by the questions about the destination (direction) of a journey, the means of transport used, and reason of the journey. The surveys are usually held under the auspices of the civil service, which ensures continual and guaranteed results. Although such surveys would be certainly profitable for the decisive actors (the Ministry of Transport, regions, and carriers) and transport researchers in Czechia, due to the universal character of the survey, the results cannot cover all the specific needs. This is the reason why, in the case of long-distance passenger transport, ${ }^{5}$ specific surveys are often carried out by the carriers themselves, who thus try to identify the potential of individual relations cutting across transport modes for their own business activities. However, results of such surveys are eventually not made public. The issue of transport surveys in long-distance transport and associated spheres is examined in a great detail by a study of the research team Axhausen et al. (2003).

If the real data are not accessible, the share of individual types of transport in the relation under observation is examined by the means of theoretical models arising from an aggregate of individual patterns of transport behaviour (in the case of a representative sample) and presumed reactions of a system to their changes. This process is represented by a group of "discrete choices" made by individuals before a journey and in its course. Specifically, a discrete choice includes the selection between two (possibly more) discontinuous alternatives. In the case of the topic under consideration, it is a choice between various means of transport (Brůhová-Foltýnová et al. 2008). In the modelling of modal split, the most frequently used methods include logit and probit models and in the case of a choice from more than two alternatives, these are their multinomial/multiple forms (Pas 1995; Pipkin 1995; Ortúzar, Willumsen 2001). In the sphere of transport, the "nested logit model" (a hierarchical model) is often used for the basic modelling of the main modes of transport. It presumes a "nested" structure of the decision-making process. This means that first, the choice is limited to the relation of individual and public transport (a "bimodal distribution"), and in the second step, an

\footnotetext{
${ }^{4}$ Such as the transport survey "Swiss Microcensus on Travel Behaviour" in which transport behaviour of the Swiss is observed in a roughly five-year period (e.g. Simma 2003). Similar information is provided by the "National Travel Survey," an annual survey of persons' mobility in Britain (DFT 2013). An overview of transport behaviour is provided for example by Marconi et al. (2004).

${ }^{5}$ In foreign literature, long-distance transport is usually defined as transport of persons over 80$100 \mathrm{kms}$, or a trip with an overnight stay (Marconi et al. 2004; Frei et al. 2010; Hubert, Potier 2003).
} 
evaluation of the main modes of public mass transport (train, bus) is made. The principle of modelling is based on the assumptions of the rational choice theory in which based on their sources (income) and limitations (primarily time and transport costs), passengers make a decision between at least two alternatives, following a certain rule in their decisions (Brůhová-Foltýnová et al. 2008). The multinomial form of the logit model arises from the following relation (e.g. Pas 1995; Ortúzar, Willumsen 2001):

$$
P_{n i}=\frac{e^{\mu V_{n i}}}{\sum_{n j \epsilon J} e^{\mu V_{n j}}}
$$

where $P_{n i}$ is probability of the choice of the observed means of transport for a given journey from the point $\mathrm{A}$ to the point $\mathrm{B} ; e$ is Euler's constant, $V_{n i}$ are generalised costs of a journey from the point $\mathrm{A}$ to the point $\mathrm{B} ; \mu$ is the parameter of sensitivity expressing the elasticity of the extent of change in the means of transport on the basis of a change in generalised costs between alternative modes of transport; and $J$ is the set of all alternative modes of transport in the observed relation A-B. There is a substantial methodological question associated with the application of models: The construction of generalised travel costs whose value influences the probability of the use of individual modes (see Chmelík, Marada 2010; Chmelík et al. 2012). In the case of individual automobile transport, these are basically all financial costs spent on a journey (i.e. the price and average consumption of fuel, fixed costs of the car operation - maintenance, insurance, vignette, etc.); in public transport, this is the fare (including customer applications determining the discounts). In all evaluated modes, there is also the time spent on a journey from point $\mathrm{A}$ to point $\mathrm{B}$, including the walk to the car, the search for a parking place or the journey to a public transport stop. The given travel time is subsequently converted into a financial value. The issues of value of time are discussed by Jain and Lyons (2008). In the construction of generalised travel costs, one can often see a constant expressing the unrecorded qualitative aspects that can be quantified with difficulties only. These are comfort, what one feels during a journey, the use of time during the journey, etc., and they considerably influence the decision on the choice of a means of transport especially in the relation "individual versus mass transport" (Riley et al., 2010). The parameter of sensitivity to the change in the generalised travel costs is another factor that enters the model. It is gained by calibration (most often by the maximum likelihood method) of the real data obtained by a transport survey or by the use of available aggregated data on the modal split in the relation under observation. This technique, which is usually used in the classical four-step transport model (e.g. Pas 1995; Ortúzar, Willumsen 2001), naturally includes only one of the alternatives (but the most known) of modelling describing the choice of the means of transport or of the modal split. ${ }^{6}$

\footnotetext{
${ }^{6}$ The method of transport resistors is another technique used in transport planning (Hrabáček 2010; Drdla 2010). In the transport and planning practice, the assessment of modal split is often conducted in a specialised software environment such as VISUM from the company PTV AG that has the advantage of possible link with GIS, programmes for the construction of timetables, etc. In sociologic disciplines, "activity based approach" has been newly applied, where a journey is considered to be only one of the attributes of activity. This is quite unlike the presented approach
} 


\section{Methodological Remarks on the Case Study}

Sixteen long-distance relations in Czechia were selected for the case study evaluating the modal split. Their travel source/destination was situated in Prague or in Brno. The evaluation focused on the share of individual automobile transport and public transport. The latter was further divided into the share of bus and rail passenger transport. For the study, the relations in which major changes in time accessibility occurred in one of the modes were primarily selected, with an assumption of impact on the modal split between 2001 and 2011. A choice was also made of the relations in which changes occurred on the transport market that influence the potential of the use of rail transport by passengers. As a rule, the modal split is assessed between the cores of agglomerations themselves. In some justified cases, further agglomerated centres in which the same transport behaviour of the population as in the core is expected were added to the core of agglomeration. The selection of the relations is presented in Table 1 and Figure 1. The size criterion for the selection was constituted by the value of 100 commuters according to the means of transport in the summary of both directions, as recorded within the 2001 Population and Housing Census (CSO 2003). Just the figures on work commuting by modes in 2001 (school commuting is not available for the 2001 Population and Housing Census) are also used as calibration data for the modelling of the modal split as of the observed years 2001, 2006 and 2011. In this respect, it is necessary to again point out the fact that the data used for the comparison with the figures from 2001 only include the movements for work that capture roughly $20-50 \%$ of all commuting movements identified. The latter only account for a fraction of total mobility (an estimate of less than 10\%). The case study is based on the assumption that the modal split in the sphere of commuting flows will display similar distribution in all purposes of journeys.

Table 1 Selection of Relations for the Assessment of Modal Split

\begin{tabular}{c|c}
\hline Origin & Destination \\
\hline \multirow{3}{*}{ Prague } & $\begin{array}{c}\text { České Budějovice, Tábor, Plzeň, Cheb (Cheb, Františkovy Lázně), Ústí Region } \\
\text { (Ústí nad Labem, Teplice, Děčín), Hradec Králové, Pardubice, Brno, Zlín+Uherské } \\
\text { Hradiště (Zlín, Otrokovice, Uherské Hradiště, Staré Město, Kunovice), Olomouc, } \\
\text { Ostrava Region (Ostrava, Opava, Havírov, Karviná), Vsetín+Valašské Meziřičí } \\
\text { Ostrava Region (Ostrava, Opava, Haviřov, Karviná), Olomouc, Zlín (Zlín, Otrokov- } \\
\text { ice), Uherské Hradiště (Uherské Hradiště, Staré Město, Kunovice) }\end{array}$ \\
\hline
\end{tabular}

in which all the processes (and choices) are connected with the journey ("trip based approach") (Brůhová-Foltýnová et al. 2008). 
Figure 1 Determination of selected relations and major transport network (in 2011)

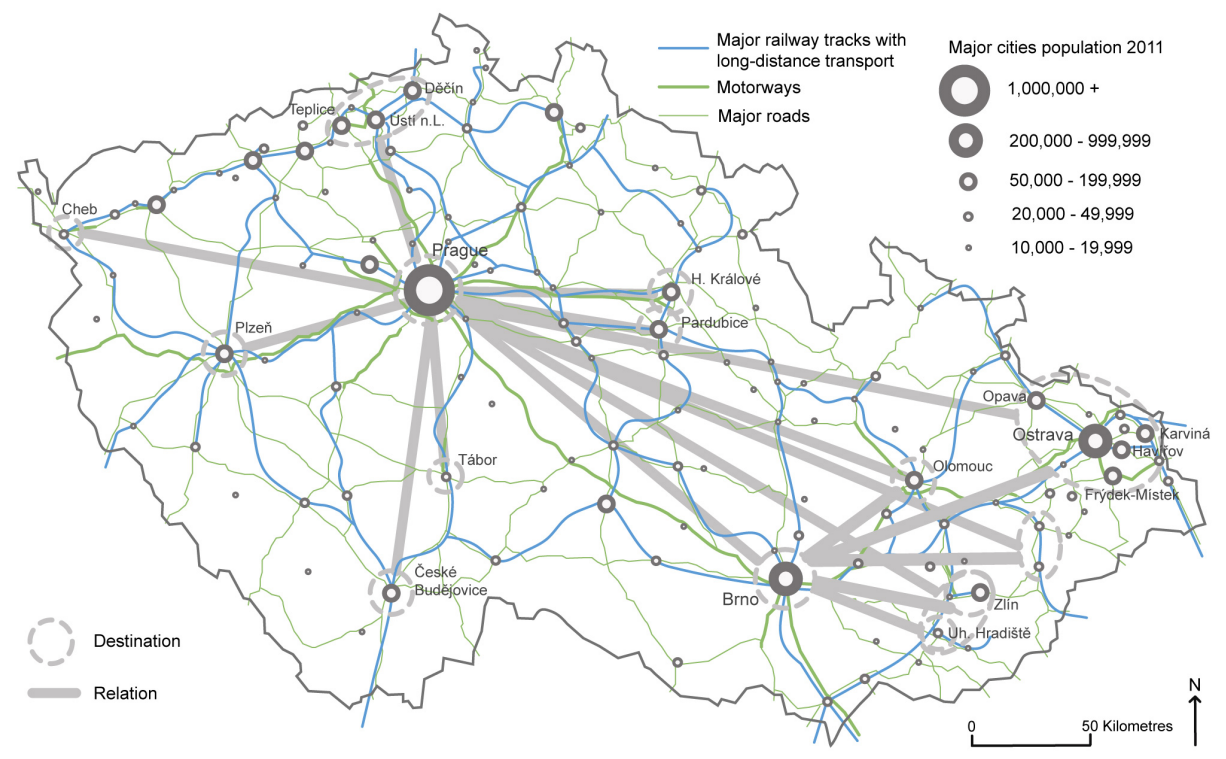

Source: CSO 2013

For the sake of an estimation of the modal split, a logit model described above, specifically the "nested logit model," was used. At first, generalised travel costs for individual automobile and public mass transport were constructed for the observed intervals. In the case of the assessed set of relations, the value of generalised costs relating to a journey by individual automobile transport was calculated by the following formula (adjusted by Riley et al. 2010):

$$
V_{\text {IAT }}=\left(D_{k m} * \frac{P_{I A T}}{O_{I A T}}\right)+\left(D_{\text {IATtime }} * W_{\text {time }}\right)+\left(D_{\text {IATacc }} * W_{\text {time }}\right)
$$

where the value $V_{I A T}$ represents generalised costs of individual automobile transport. The length of a journey $\left(D_{k m}\right)$, given in kilometres, was recorded as of 2012 by the means of a journey planner (Journey planner 2012). It was estimated for the observed intervals on the basis of the state of construction of the motorway network. In a similar way, the distance in time $\left(D_{\text {IATtime }}\right)$ between the cores of agglomerations was estimated. In the case of multiple-core agglomerations, the value was calculated as referenced to their geographic centre, taking into account the weight of population size. At the same time, there was the inclusion of the indicator of accessibility $\left(D_{\text {IATaCc }}\right)$ or walk to an automobile as well as search for the parking place etc. that also rectified the differences between the time accessibility of centres. The bigger centres were ascribed a higher value of accessibility due to the generally large dispersion of values (town centre versus outskirts) in the time accessibility itself $\left(D_{\text {IATtime }}\right)$. The operating costs of an automobile per 1 kilometre of a journey $\left(P_{I A T}\right)$ are constructed as a sum of average consumption of fuel of a usual car (the paper reckons with the value of 7 litres per $100 \mathrm{kms}$ ) plus 
minimal average fixed costs (e.g. highway fee, car insurance, periodically repairs, etc.) calculated in the compensation tariffs for the use of automobiles at business trips (prices of fuel and reimbursement of travel, Ministry of Finance 2012). ${ }^{7}$ For this reason, operating costs are considerably generalised and do not take into account any regional specificities. Due to the accessibility of the relevant data, the values for Czechia were used in all cases. The average occupancy of an automobile $\left(O_{I A T}\right)$ was set to two persons. The value best corresponds to information from foreign studies in the sphere of longdistance transport (e.g. Hubert, Potier 2003). However, total values for all transport segments are usually lower as, for example, in the latest survey of transport behaviour conducted in Switzerland (FSO 2012), where the average occupancy of an automobile was in the interval of 1.12 to 2.05 depending on the purpose of the journey (daily commuting to work versus leisure time activities). The model included another component: The indicator of perceived hourly value of the time spent on a journey $\left(W_{\text {time }}\right)$, construction of which was based on a methodological manual for modelling created for the Transport Ministry (Riley et al. 2010). The indicator included the average sum of hourly wages in regions (average gross monthly salary in 2001, 2006, 2011; CSO2012) which was multiplied by the coefficient 0.24 (adopted from Riley et al. 2010, p. 78) in which the observed agglomerations for specific relations were found.

Generalised costs for the connection by public transport (by bus and train) were subsequently constructed for the same set of relations. The technique was the same for both modes. When a comparison was made with automobile transport, there was a consideration of the values for the mode that is more advantageous from the viewpoint of a rational passenger, especially as far as time is concerned. The calculation for public transport was based on the following relation (adjusted by Riley et al. 2010):

$$
V_{P T}=\left[\left(D_{P T t i m e} * W_{\text {time }}\right)+\left(D_{P T a c c} * W_{\text {time }}\right)+F+I_{1 / 2}\right] * C_{P T-I A T}
$$

where the value of $V_{P T}$ represents generalised costs of public transport. Similarly to the case of automobile, the time accessibility to a means of transport $\left(D_{P T a c c}-\right.$ a journey to a railway station, stop) was gained by an estimate and an indicator of perceived hourly value of the time of a person on a journey $\left(W_{\text {time }}\right)$ was constructed. The distance in time of centres $\left(D_{\text {PTtime }}\right)$ is based on travel times of buses and trains to the most frequented railway and bus stations given in specific timetables (electronic timetable - IDOS 2001, 2006, 2011). In the case of multiple-core centres, the travel time was adjusted by the geographic centre of the agglomeration, similarly to the case of automobile connection. Modal travel time ${ }^{8}$ was used which most corresponds to the real systemic offer and is not affected by extra links. The extent of the offer itself $\left(I_{1 / 2}\right)$ was quantified as one half of the typical interval of a line (lines) in a relation, which expressed the discontinuous offer of public transport unlike that of individual transport. When it comes to the nonsystemic offer with a minimum of lines per day, the value of a four-hour interval was

\footnotetext{
${ }^{7}$ Fixed cost for the setting of the operating costs of an automobile per 1 kilometre was calculated for about CZK 1 per $\mathrm{km}$ in average. This value is very close of the value used in the methodological study by Riley et al. (2010).

${ }^{8}$ Average travel time was used for the relations with differing transport offer.
} 
used. The usual March Wednesday ${ }^{9}$ was the referential day for the calculations from the timetable. Direct financial costs borne by a passenger are expressed by the price of the fare $(F)$. In the case of rail transport, the fare was related to the prices of passenger fare (i.e. after a $25 \%$ discount from the basic fare; without the inclusion of relation discounts) for 2011 as given by the tariff of the Czech Railways (ČD TR 10 2010), the most important carrier in Czechia. Due the inaccessibility of older data, the prices of bus tickets are related to the values valid in spring 2012. As there was a variety of carriers, the figure depicted for the lines in the station finder (IDOS 2012) was almost invariably used as the most common price. Due to their difficult availability, the data for 2001 and 2006 were estimated. In principle, the latest value in a time series was always adjusted by a coefficient that roughly respected the development of the railway tariff of the Czech Rail. When it comes to the construction of generalised costs for public transport, the calibration constant of the transport mode choice $\left(C_{P T-I A T}\right)$ that ensures a concurrence of the real and model modal splits was also included.

After the generalised travel costs were constructed, the logit model was calibrated. This required that the value of the parameter $\mu$ be found, i.e. parameter which, based on a change in generalised costs among alternative modes of transport within the set of observed relations in which similar reactions to changes are presumed, expresses the elasticity of change in the means of transport. The data on commuting by modes from the 2001 Population and Housing Census (CSO 2003) were used for the calibration. The value $\mu$ was estimated by the maximum likelihood method, at first for the relation between individual automobile transport and public mass transport. In the second step, it was applied on the relation between the rail passenger transport and regular bus transport. In the case of the first step it was also necessary to estimate $C_{P T-I A T}$ (the constant of the transport mode choice) in such a way that the value of $\mu$ was as close as possible to the interval appearing in foreign studies ${ }^{10}$ (for greater detail see Riley et al. 2010 , p. 88). A weighing of the costs of public transport by the constant $C_{P T-I A T}$ was necessary because simple costs of public transport were always considerably lower than those of the automobile. In reality, this would mean that individual automobile transport has a negligible share in the modal split. This disproportion is most affected by the difficult quantification of soft, non-financial influences (quality, comfort, privacy, security, etc.) on transport behaviour of population. The most suitable parameter for the relation between individual automobile and public transport $\mu=-0.0031$ was reached with the constant $C_{P T-I A T}=2.2$. When it comes to the relation between rail passenger and regular bus transport, the parameter reached the value $\mu=-0.0123$. The values of the parameters were subsequently used for an estimate of the modal split model for the intervals under observation.

\footnotetext{
${ }^{9}$ The usual March Wednesday was selected because it poses no limitations (weekends, Easter holiday were in April in 2001, 2006 and 2011) or additional measures (for example additional trains in peaks on Fridays and Sundays) (see also Chmelík et al. 2010).

${ }^{10}$ Interval between -0.1 and -0.01 .
} 


\section{Results}

A comparison of the share of individual automobile transport and public transport in individual relations has yielded interesting results. In general, there is an obvious falling share of public transport in the modal split in the period under observation, while higher dynamics of changes is predicted for its second half. This is apparent from Table 2, where the value of the share of public transport in the modal split is compared to the average value of public transport for the whole Czechia calculated from the statistics of the Ministry of Transport ${ }^{11}$ (Ministry of Transport 2013a). According to the model, out of the 16 monitored relations, 13 were above the average in 2001 and 2006, but only 10 in 2011. A general growth in the use of automobile in the model was enhanced, among others, by a large number of motorways and further road projects having been put into operation, which influenced the time accessibility of the observed centres with an impact on the lowering of generalised travel costs. There was only the following exception in the survey: the relation Prague-Vsetín/Valašské Meziř́íčí, where the proportion of public transport increased slightly between 2006 and 2011, probably due to the high level of the train connection in 2011. In the relation Prague-Pardubice where, according to the model, public transport accounted for the biggest share (mainly high share of railways), for over $40 \%$ of the transport demand between 2001, 2006 and 2011. As far as all other relations are concerned, there was always a predominance of the use of automobile in 2001, 2006 and in 2011, usually exceeding 60\%. However, it must be noted in this respect that the decreases cannot be appropriately assessed and they are rather questionable in a number of cases. Given the large variety of offer and travel time on rail, for example, the 9\% fall in the relation Prague-Ostrava Region between 2006 and 2011 is unlikely. This is even more unlikely at present, when three carriers operate in the relation Prague-Ostrava Region/Olomouc, while its representatives stated that the market share of the railways has increased here. However, due to the time limit as of 2011, the latest change in offer was not included in the estimate. As a rule, the most important values above the described national average of the share of public transport were reached among the relations with the location on rail corridors or with an adequate offer of the connections of both main modes of public transport. The model ascribed the lowest proportion of the use of public transport to the relations that are less frequented from the viewpoint of intensity of transport (Prague-Cheb, Vsetín/Valašské Meziříčí) or are described by a rather small set of the real data entering the calibration, which affects their informative value. Moreover, the real values of the share of observed modes correspond to the model data just in these relations. A similarly considerable difference between real and model data is obvious in the relation Prague-Pardubice, where the model predicted a higher share of the use of individual automobile transport than that found in the real data. In general, it is necessary to stress again in this connection that the real data presented in the Table 2 and that were used for the calibration of the model only include the journeys to work. In a number of relations, this fact can strongly affect the

\footnotetext{
${ }^{11}$ The value of the share of public transport (33\% in 2001, 31\% in 2006, and $32 \%$ in 2011) arises from the sum of transport outputs for railway, bus and urban mass transport.
} 
share of public transport that is often the main bearer of transport demand in commuting to schools.

Table 2 Resulting Estimates of the Share (\%) of Individual Automobile Transport and Public Transport in Modal Split (2001, 2006, 2011)

\begin{tabular}{|c|c|c|c|c|c|c|c|c|c|c|}
\hline \multirow{2}{*}{ Relation/Year } & \multicolumn{2}{|c|}{$2001 \mathrm{R}$} & \multicolumn{2}{|c|}{$2001 \mathrm{E}$} & \multicolumn{2}{|c|}{$2006 \mathrm{E}$} & \multicolumn{2}{|c|}{$2011 \mathrm{E}$} & \multicolumn{2}{|c|}{$2011 \mathrm{R}$} \\
\hline & IAT & PT & IAT & PT & IAT & PT & IAT & PT & IAT & PT \\
\hline Prague - České Budějovice & 67 & 33 & 60 & $40^{1}$ & 64 & $36^{1}$ & 70 & 30 & 67 & 33 \\
\hline Prague- Tábor & 65 & 35 & 58 & $42^{1}$ & 61 & $39^{1}$ & 64 & $36^{1}$ & 59 & 41 \\
\hline Prague - Plzeň & 63 & 37 & 59 & 411 & 62 & 381 & 63 & 371 & 64 & 36 \\
\hline Prague - Cheb Region & 55 & 45 & 72 & 28 & 76 & 24 & 81 & 19 & 61 & 39 \\
\hline Prague - Ústí Region & 53 & 47 & 61 & $39^{1}$ & 63 & $37^{1}$ & 66 & $34^{1}$ & 55 & 45 \\
\hline Prague - Hradec Králové & 70 & 30 & 57 & $43^{1}$ & 60 & $40^{1}$ & 63 & $37^{1}$ & 61 & 39 \\
\hline Prague - Pardubice & 50 & 50 & 54 & $46^{1}$ & 55 & $45^{1}$ & 59 & $41^{1}$ & 40 & 60 \\
\hline Prague - Brno & 72 & 28 & 64 & $36^{1}$ & 67 & $33^{1}$ & 72 & 28 & 68 & 32 \\
\hline Prague - Zlín+Uh.Hradiště & 67 & 33 & 71 & 29 & 77 & 23 & 80 & 20 & 72 & 28 \\
\hline Prague - Olomouc & 57 & 43 & 60 & $40^{1}$ & 63 & 371 & 67 & 331 & 50 & 50 \\
\hline Prague - Ostrava Region & 59 & 41 & 64 & $36^{1}$ & 65 & $35^{1}$ & 74 & 26 & 56 & 44 \\
\hline Prague - Vsetín+V.Meziříčí & 68 & 32 & 75 & 25 & 81 & 19 & 79 & 21 & 53 & 47 \\
\hline Brno - Ostrava Region & 67 & 33 & 59 & $41^{1}$ & 59 & $41^{1}$ & 67 & $33^{1}$ & 67 & 33 \\
\hline Brno - Olomouc & 61 & 39 & 60 & $40^{1}$ & 62 & $38^{1}$ & 67 & 33 & 75 & 25 \\
\hline Brno - Zlín & 70 & 30 & 61 & $39^{1}$ & 63 & $37^{1}$ & 67 & 33 & 79 & 21 \\
\hline Brno - Uherské Hradiště & 58 & 42 & 58 & $42^{1}$ & 59 & $41^{1}$ & 62 & $38^{1}$ & 72 & 28 \\
\hline
\end{tabular}

Note: 1) the value of the share of public transport is higher than the average value of the share of public transport for the whole Czech Republic, $R=$ real data, $E=$ model estimate

Source: CSO 2003, 2013, author's calculations

The results of the second model that estimated the shares of railway and bus transport in the modal split in public transport deserve a comprehensive discussion. As generalised costs are constructed in the same way in both cases, one can expect it to have higher informative value. Besides, unlike the previous model, the real values of the shares can be more easily estimated thanks to the knowledge of the real offer of connections that is supposed to better reflect the real demand arising from the time competitiveness of both observed modes. Based on the results presented in Table 3, it can be stated that according to the estimate of the model, there were no major transformations of the prevailing mode in the individual relations in the period under observation. In 2001, railway transport was more used in 7 out of 16 relations, and in 8 relations in 2006 and 2011. From the viewpoint of the development of the shares, one can delineate several groups of relations with similar characteristics.

The first group is constituted by the relations where a higher share of railway transport was estimated by the model in all observed intervals. Higher dynamics of changes was 
rather predicted for the second half of the examined period. This fact is primarily influenced by the extended variety of offer of rail transport that was associated with the use of modernised railway corridors. In fact, a higher share of railway transport was also recorded in the case of real values from 2011. When it comes to spatial distribution, this group primarily included the relations heading from the east to Prague, which means the lines from Pardubice, Olomouc, the Zlín Region and the Ostrava Region. Despite a high share of railways in these relations, the results are questionable because due to the negligible offer of bus connections, even lower use of buses can be expected in reality. This is apparent for example in the relation Prague-Pardubice, where the model for 2011 predicts a $13 \%$ share of bus, but the real data on commuting say it only amounts to $6 \%$. In fact, the bus connection is roughly twice as long as far as time is concerned, and it is also necessary to change in Hradec Králové. In this respect, one can discuss the methodological question of time disadvantage of interchange lines (at least of the bus lines that are not common, unlike the railway network offer) or the highest possible interval of offer (the study reckons with one half of the four-hour interval). Along with the above, i.e. typical railway relations, the group can also include the relations BrnoOstrava Region and Prague-Cheb in which a higher share of railway transport use was recorded in all observed years, but in the first half of the observed period it was decreasing.

The second group is formed by the relations in which higher proportion of bus transport in the modal split of public transport was recorded in all observed intervals. Basically, this referred to the selected radial link to Prague (from Brno, Plzeň, České Budějovice, Tábor and Hradec Králové) and the connection to Brno from central and eastern Moravia (Olomouc, Zlín and Uherské Hradiště). The result in these relations was mainly determined by railway infrastructure which - when it comes to time accessibility - is able to compete with road transport only to a limited degree. In the case of Czech relations, apart from a lower model share (though growing between 2001 and 2006) in the connection Prague-Plzeň/České Budějovice, one could see a steep fall in real values of the share between 2001 a 2011, which occurred, according to the model, in the second half of the observed period. This trend can be associated with the ongoing construction of the third and fourth transit rail corridors that had a negative impact on travel comfort (prolongation of travel times, instability of the timetable, or frequent closures). On the other hand, the bus competition offers here a relatively wide and systemic offer of links. The most significant discrepancy between the model and the real shares was found in the relation Prague-Plzeň, where the model ascribed to the railway an almost double proportion compared with the data on commuting by mode in 2011. In the case of Moravian "bus" relations, the model slightly underestimates the share of the rail in the connections of Brno and Olomouc, as compared with the real shares, while it overestimates it in the relations Brno-Uherské Hradiště/Zlín. Due to a longer travel time, the systemic offer of railway connection for passengers probably does not offer any adequate competition here.

The relation Prague-Ústí nad Labem remained in the third group. Partial changes in the preferred mode occurred in it between the observed intervals. In 2001, bus transport had a slightly higher share, but it was railway transport in the following intervals. A significant increase was recorded between 2006 and 2011. The result can be attributed to the reconstruction of the line connecting Prague with Ústí nad Labem, and the subsequent 
widening of the offer of connections after 2006. Despite this, the resulting model share of rail in 2011 is still much lower than the real values by the mode used for commuting.

Table 3 Resulting Estimates of the Share (\%) of Train and Bus in Public Transport Modal Split (2001, 2006, 2011)

\begin{tabular}{l|cc|cc|cc|cc|cc|}
\hline \multirow{2}{*}{ Relation/Year } & \multicolumn{2}{|c|}{$2001 \mathrm{R}$} & \multicolumn{2}{|c|}{$2001 \mathrm{E}$} & \multicolumn{2}{c|}{$2006 \mathrm{E}$} & \multicolumn{2}{c|}{$2011 \mathrm{E}$} & \multicolumn{2}{c}{$2011 \mathrm{R}$} \\
\cline { 2 - 10 } & $\mathrm{T}$ & $\mathrm{B}$ & $\mathrm{T}$ & $\mathrm{B}$ & $\mathrm{T}$ & $\mathrm{B}$ & $\mathrm{T}$ & $\mathrm{B}$ & $\mathrm{T}$ & $\mathrm{B}$ \\
\hline Prague - České Budějovice & 52 & 48 & 46 & 54 & 48 & 52 & 45 & 55 & 44 & 56 \\
Prague- Tábor & 51 & 49 & 44 & 56 & 46 & 54 & 45 & 55 & 52 & 48 \\
Prague - Plzeň & 39 & 61 & 43 & 57 & 43 & 57 & 36 & 64 & 21 & 79 \\
Prague - Cheb Region & 66 & 34 & 54 & 46 & 53 & 47 & 65 & 35 & 49 & 51 \\
Prague - Ústí Region & 58 & 42 & 49 & 51 & 51 & 49 & 68 & 32 & 81 & 19 \\
Prague - Hradec Králové & 53 & 47 & 41 & 59 & 45 & 55 & 42 & 58 & 35 & 65 \\
Prague - Pardubice & 87 & 13 & 77 & 23 & 84 & 16 & 87 & 13 & 94 & 6 \\
Prague - Brno & 26 & 74 & 37 & 63 & 34 & 66 & 37 & 63 & 34 & 66 \\
Prague - Zlín+Un.Hradiště & 44 & 56 & 59 & 41 & 62 & 38 & 73 & 27 & 58 & 42 \\
Prague - Olomouc & 85 & 15 & 82 & 18 & 82 & 18 & 93 & 7 & 89 & 11 \\
Prague - Ostrava Region & 65 & 35 & 76 & 24 & 71 & 29 & 89 & 11 & 85 & 15 \\
Prague - Vsetín+V.Meziříći & 56 & 44 & 67 & 33 & 71 & 29 & 82 & 18 & 79 & 21 \\
Brno- Ostrava Region & 73 & 27 & 63 & 37 & 53 & 47 & 66 & 34 & 78 & 22 \\
Brno - Olomouc & 55 & 45 & 49 & 51 & 47 & 53 & 49 & 51 & 51 & 49 \\
Brno-Zlín & 20 & 80 & 44 & 56 & 44 & 56 & 45 & 55 & 30 & 70 \\
Brno- Uherské Hradiště & 31 & 69 & 39 & 61 & 36 & 64 & 36 & 64 & 24 & 76 \\
\hline
\end{tabular}

Note: $T=$ train, $B=$ bus $R=$ real data, $E=$ model estimate

Source: CSO 2003, 2013, author's calculations

In general, the results of both models mainly confirm the changes in significance of modal split of public transport caused by important infrastructure improvements of railway corridors. In the field of long-distance rail transport were in this context increased number of trains which were able to compete road transport in the travel time. On the other hand, the real results could perhaps be better because only selected railway infrastructure projects had been finished in the past decade. This situation is also influenced by quite a low level of the infrastructure planning in Czechia after 1989, when many projects were conceived by the old transport strategy and did not reflect the change of transport demand and traffic behaviour. The hierarchy of priorities of new infrastructure and also comprehensive study based on the transport model including modelling of the changes of modal split was not made in Czechia in the past. (Chmelík, Marada 2014). Absence of complex view of transport infrastructure strategy is newly dealt by the Ministry of Transport by the project "Transport Sector Strategy, 2nd Phase". This strategy is based on the new national multi-modal transport model (Vachtl et al. 2013). 


\section{Conclusion}

The goal of this paper was to present basic alternatives of the assessment of modal split by the main transport modes. One of the chief methods was subsequently applied on a delineated set of long-distance relations in Czechia. Before the case study was drafted, the issue of accessibility of the real data on the use of individual transport modes had been discussed. In this connection, the situation in the European countries with advanced transport conditions (Switzerland, Germany, the United Kingdom, etc.) was briefly outlined. In these countries, rather comprehensive transport surveys have been made that considerably expand the information base with the knowledge transport behaviour of the population. It is important to note that transport surveys are usually conducted by decision-making bodies as well as by organisations that report to them. In this respect, it may be desirable to stage a relevant discussion on the issue in the Czech Republic and to define the need of the data and end users. As the need of any surveys of transport behaviour and consumer polls is not mentioned even marginally in the basic strategic document named Transport Policy of the Czech Republic for 2014-2020 With a Prospect Until 2050 (Ministry of Transport 2013b), the Ministry of Transport cannot be expected to take any major initiative in this field. In fact, some information, primarily that gained by a survey, can have vital impact on many spheres of transport planning. In the case study, this can be exemplified by the used weight of the perceived value of the time spent on a journey (by the type of vehicle) or while waiting for a connection that is usually adopted from foreign studies in the conditions of Czechia. The value is further used for economic assessment, for example, but it is possible that due to different transport behaviour of population and its economic situation, etc., the results of the studies in Western Europe do not reflect the assumptions expected in the case of Czechia.

The core of the contribution was formed by a case study within which the used methodology was tested. It involved the construction of "universal" generalised travel costs and a subsequent application of the logit model. This resulted in a rather interesting comparison of the shares of individual transport modes in the relations under observation. In general, the assumptions were confirmed. The model estimate revealed that the share of individual automobile transport was rising in the observed intervals and, in a number of cases, even more than in the case of the development of the real data, although they included one part of common mobility. As suggested, when it comes to the share of rail and bus transport, higher growth was recorded in the relations along rail corridors, especially in the second half of the observed period. The development was not so dynamic in the relations with a prevailing proportion of bus and a in a number of cases it even stagnated. It is important to note that the model results are influenced by the usage of a set of calibration data as of 2001, and furthermore significantly follow the definition of travel costs. These are far from being able to incorporate all the relevant factors influencing the decisions of actors of the transport process in their transport behaviour. However, in the case of long-distance relations, it is difficult to thoroughly verify the informative value of the model due to the size of the transport market, especially in individual journeys. This suggests verification by a similar survey on a lower regional order that could then be confronted with a detailed field survey in the area. Nevertheless, the results confirmed that the application of the basic logit model can give very valuable outputs. 


\section{References}

AXHAUSEN, K. W., MADRE, J.-L., POLAK, J. W., TOINT, Ph. (eds.). (2003). Capturing Long-Distance Travel. Research Studies Press, Baldock, 342 p.

BRU゚HOVÁ-FOLTÝNOVÁ, H. a kol. (2008). Analýza každodenního dopravního chování dospělého městského obyvatelstva a nástroje regulace dopravy. Závěrečná zpráva z projektu MD 24/2006-430-OPI/3 z OP „Infrastruktura“ - Priorita 2 (2.4). Univerzita Karlova v Praze, Centrum pro otázky životního prostředí, 281 p.

BURGE, P., KIM, CH. W., ROHR, CH. (2011). Modelling Demand for Long-Distance Travel in Great Britain: Stated preference surveys to support the modelling of demand for high-speed rail. Prepared for the UK Department of Transport, RAND Europe, $65 \mathrm{p}$.

ČD TR 10 (2010). Czech Railways Tariff for domestic passengers and baggage transport, change no. 4 valid from 12.12.2010.

CHARLTON, C., VOWLES, T. (2008). Inter-urban and regional transport. In: Knowles, R., eds.: Transport geographies: Mobilities, Flows and Spaces. Blackwell Publishing Ltd., Oxford, pp. 120-136.

CHMELÍK, J., KVĚTOŇ, V., MARADA, M. (2012). Možnosti hodnocení “modal splitu” hlavních dopravních módi̊ v Česku: př́klad vybraných dálkových spojení v Česku. In: Seminář Telč 2012: Konkurence na železnici - budoucnost pro 21. století nebo destrukce sítě? (presentation), 12 p.

CHMELÍK, J., MARADA, M. (2010). Konkurence dopravních módů na vybrané relaci v Česku. In: Seminář Telč 2010: Konkurence na evropských železnicích - ekonomické, právní a regionální faktory (presentation), $15 \mathrm{p}$.

CHMELÍK, J., MARADA, M. (2014): Assessment of the impact of a new motorway connection on the spatial distribution and intensity of traffic flows: A case study of the D47 motorway, Czech Republic. Moravian Geographical Reports, Vol. 22, No. 4, pp. 14-24. DOI: $10.1515 / \mathrm{mgr}-2014-0020$

CHMELÍK, J., KVĚTOŇ, V., MARADA, M. (2010). Evaluation of competitiveness of rail transport on example of connection among regional capitals in Czechia. Národohospodářský obzor / Review of Economic Perspectives, 10, No 1, Masarykova univerzita v Brně, Brno, pp. 5-20.

CSO (2003). Population and Housing Census 2001: Commuting to work and schools: The Czech Republic. Czech Statistical Office, Prague.

CSO (2012). Average gross salary 2001, 2006, 2011: Regional Time Series. Czech Statistical Office. Retrieved April 17, 2012, from http://www.czso.cz/csu/redakce.nsf/i/ regionalni_casove_rady

CSO (2013). Population and Housing Census 2011: Commuting to work and schools: The Czech Republic. Czech Statistical Office, Prague.

DFT (2013). National Travel Survey. Department for Transport. Retrieved October 15, 2013 from https://www.gov.uk/government/ collections/national-travel-survey-statistics 
DRDLA, P. (2010). Posouzení využití metodiky dopravních odporů. Vol. V, No 1, Perner's Contacts, pp. 47-56.

FREI, A., KUHNIMHOF, AXHAUSEN, K. W. (2010). Long distance travel in Europe today: Experiences with a new survey, paper presented at the 89th Annual Meeting of the Transportation Research Board, Washington, D. C., January 2010. Retrieved October 15, 2013, from http://e-collection.library.ethz.ch/eserv/eth:715/eth-715-01.pdf

FSO (2012): Mobilität in der Schweiz: Ergebnisse des Mikrozensus Mobilität und Verkehr 2010. Neuchatel, Federal Statistical Office, 115 p.

GOETZ, A. R., VOWLES, T. M., TIERNEY, S. (2009). Bridging the QualitativeQuantitative Divide in Transport Geography. Professional Geographer, 61, No 3, pp. 323-335.

HAMPL, M. (2005). Geografická organizace společnosti v České republice: Transformační procesy a jejich obecný kontext. PřF UK, Praha, 147 p. + map appendix.

HORŇÁK, M., PŠENKA, T. (2013): Verejná doprava jako indikátor medzisídelných väzieb medzi mestami Slovenska. Geografický časopis. Vol. 65, No. 2, pp. 119-140.

HORŇÁK, M., PŠENKA, T., KRIŽAN, F. (2013): The competitiveness of the longdistance public transportation system in Slovakia. Moravian Geographical Reports. Vol. 21, No. 4, pp. 64-75.

HRABÁČEK, J. (2010). Dopravní odpor a možnosti jeho využití při posouzení modal split (metoda RWTH Aachen). In: Seminář Telč 2010: Konkurence na evropských železnicích - ekonomické, právní a regionální faktory. Recenzovaný sborník př́ispěvků. ESF MU v Brně, pp. 120-135.

HUBERT, J. P., POTIER, F. (2003). What is known? In: Axhausen, K. W., Madre, J.L., Polak, J. W., Toint, Ph. (eds.): Capturing Long-Distance Travel. Research Studies Press, Baldock, pp. 45-70.

IDOS (2001): Electronic timetable. CHAPS spol. s.r.o.

IDOS (2006): Electronic timetable. CHAPS spol. s.r.o.

IDOS (2011): Electronic timetable. CHAPS spol. s.r.o.

IDOS (2012): Electronic timetable. CHAPS spol. s.r.o.

JAIN, J., LYONS, G. (2008): The gift of travel time. Journal of Transport Geography, 16, 2, pp. 81-89.

Journey planner (2012). Retrieved April 12, 2012, from www.mapy.cz

KEELING, D. (2008). Transportation geography - new regional mobilities. Progress in Human Geography, 32, 2, pp. 275-283.

KRAFT, S., VANČURA, M. (2009a): Geographical organization of the transport system in Czechia and its development in the transformation period. Geografie, 114, 4, pp. 298-315. 
KRAFT, S., VANČURA, M. (2009b). Dopravní systém České republiky: efektivita a prostorové dopady. Národohospodářský obzor / Review of Economic Perspectives, 9, No. 1, Masarykova univerzita v Brně, Brno, pp. 21-33.

KVIZDA, M. (2011). Vymezování relevantního trhu v odvětví železniční dopravy. In: Kvizda, M., Tomeš, Z. (eds.): Regulace konkurenčního prostředí na železnici - teorie v centru a praxe v regionech. Semináŕ Telč 2011 - sborník příspěvků. Ekonomickosprávní fakulta, Masarykova univerzita v Brně, pp. 49-64.

KVIZDA, M., REDERER, V. (2012). Použití spotřebitelského šetření k vymezování relevantního trhu v železniční dopravě - možnosti a problémy. In: Kvizda, M., Tomeš, Z. (eds.): Konkurence na železnici - budoucnost pro 21. století nebo destrukce sítě? Seminář Telč 2012 - sborník příspěvků. Ekonomicko-správní fakulta, Masarykova univerzita v Brně, pp. 32-45.

KVIZDA, M., SEIDENGLANZ, D. (2014): Out of Prague: a week-long intermodal shift from air to rail transport after Iceland's Eyjafjallajökull erupted in 2010. Journal of Transport Geography, 37, pp. 102-111. DOI:10.1016/j.jtrangeo.2014.04.014.

MARADA, M. (2006). Vertikální a horizontální dopravní poloha středisek osídlení Česka. In: Kraft, S., Mičková, K., Rypl, J., Švec, P., Vančura, M.: Česká geografie v evropském prostoru, elektronický sborník př́íspěvků (CD-ROM) z XXI. sjezdu České geografické společnosti, katedra geografie, Pedagogická fakulta, Jihočeská univerzita v Českých Budějovicích, pp. 169-174.

MARADA, M., KVĚTOŇ, V., MATTERN, T., ŠTYCH, P., HUDEČEK, T. (2014): Accessibility patterns: Czech Republic Case Study. EUROPA XXI, Vol. 24, 2013, pp. 61-76.

MARADA, M., KVĚTOŇ, V., VONDRÁČKOVÁ, P. (2010). Doprava a geografická organizace společnosti $v$ Česku. Edice Geographica, ČGS, Praha, 165 p.

MARADA, M., KVĚTOŇ, V. (2010). Diferenciace nabídky dopravních př́iležitostí v českých obcích a sociogeografických mikroregionech. Geografie, 115, 1, pp. 21-43.

MARCONI, D., SIMMA, A., GINDRAUX, M. (2004). The Swiss Microcensus 2005: An International Comparison on Travel Behaviour. Paper for 4rd Swiss Transport Research Conference, Ascona, March 2004. 19 p. Retrieved October 11, 2012, from http://www.strc.ch/conferences/2004/Marconi_Simma_Gindraux_SwissMicrocensus20 05_STRC_2004.pdf

Ministry of Finance (2012). Prices of fuel and reimbursement of travel. Ministry of Finance of the Czech Republic. Retrieved April 19, 2012, from http://www.mfcr.cz/cs/legislativa/cestovni-nahrady

Ministry of Transport (2013a). Transport Yearbook of The Czech Republic (19982012). Ministry of Transport of the Czech Republic. Retrieved October 15, 2013 from https://www.sydos.cz/cs/rocenky.htm

Ministry of Transport (2013b). Transport Policy of the Czech Republic for 2014-2020 With a Prospect Until 2050. Ministry of Transport of the Czech Republic. Retrieved 
October 20, 2013 from http://www.mdcr.cz/NR/rdonlyres/6771FC27-DCCC-4B72BD0E-3EF7E6118704/0/Dopravnipolitika20142020schvalena.pdf

MULÍČEK, O., OSMAN, R., SEIDENGLANZ, D. (2013): Imaginace a reprezentace prostoru v každodenní zkušenosti. Sociologický časopis / Czech Sociological Review, AV ČR, Sociologický ústav, Vol. 49, No. 5, pp. 781-810.

ORTÚZAR, J. D., WILLUMSEN, L. (2001). Modelling Transport, Third Edition. John Wiley, Chichester, 499 p.

PAS, E. I. (1995). The Urban Transportation Planning Process. In: Hanson, S., ed.: The Geography of Urban Transportation - second edition. The Guilford Press, London, pp. $53-77$.

PIPKIN, J. S. (1995). Disaggregate Models of Travel Behaviour. In: Hanson, S., ed.: The Geography of Urban Transportation - second edition. The Guilford Press, London, pp. 188-218.

PRESTON, J., O’CONNOR, K. (2008). Revitalized transport geographies. In: Knowles, R., eds.: Transport geographies: Mobilities, Flows and Spaces. Blackwell Publishing Ltd., Oxford, pp. 227-237.

RIETVELD, P., BRUINSMA, F. (1998). Is Transport Infrastructure Effective? Transport Infrastructure and Accessibility: Impacts on the Space Economy. Springer-Verlag, Berlin - Heidelberg, 383 p.

RILEY, P. et al. (2010). Lokálně ověrený rámec pro multimodální modelování poptávky po veřejné dopravě osob $v$ souvislosti $s$ interními a externími kvalitativními a ekonomickými faktory dopravní obsluhy. Závěrečná zpráva z projektu VaV MD č. CG721-045-190. Jacobs Consultancy, 162 p.

RODRIGUE, J.-P., COMTOIS, C., SLACK, B. (2006). The Geography of Transport Systems. Routledge, London, 284 p.

SEIDENGLANZ, D. (2009). Konkurenceschopnost železniční a letecké dopravy. In: Kvizda, M., Tomeš, Z. (eds.): Konkurenceschopnost a konkurence v železniční dopravě - ekonomické, právní a regionální faktory konkurenceschopnosti železnice. Seminár Telč 2009 - recenzovaný sborník příspěvků. Ekonomicko-správní fakulta, Masarykova univerzita v Brně, pp. 72-86.

SHAW, J., KNOWLES, R., DOCHERTY, I. (2008). Introducing Transport Geographies. In: Knowles, R., eds.: Transport geographies: Mobilities, Flows and Spaces. Blackwell Publishing Ltd., Oxford, pp. 3-9.

SHELLER, M., URRY, J. (2006). The new mobilities paradigm. Environment and Planning A, 38, Pion, pp. 207-226.

SHEPPARD, E. (1995). Modelling and Predicting Aggregate Flows. In: Hanson, S., ed.: The Geography of Urban Transportation - second edition. The Guilford Press, London, pp. 100-128.

SIMMA, A. (2003). History of the Swiss Travel Surveys, Swiss Federal Office for Spatial Development, paper for 3rd Swiss Transport Research Conference, Ascona, March 
2003. 23 p. Retrieved October 11, 2012, from http://www.strc.ch/conferences/2003/simma.pdf

STRANDLING, S., ANABLE, J. (2008). Individual transport patterns. In: Knowles, R., eds.: Transport geographies: Mobilities, Flows and Spaces. Blackwell Publishing Ltd., Oxford, pp. 179-195.

TEMElOVÁ, J., NOVÁK, J., POSPÍŠILOVÁ, L., DVOŘÁKOVÁ, N. (2011). Každodenní život, denní mobilita a adaptační strategie obyvatel v periferních lokalitách. Sociologický časopis / Czech Sociological Review, Vol. 47, No 4. pp. 831-858

TSK (2013): Transport Yearbook - Prague (1988-2012). Technical Administration of Roadways of the Capital of Prague (TSK). Retrieved October 15, 2013 from http://www.tsk-praha.cz/wps/portal/doprava/web/pro-odborniky/rocenky

VACHTL, M. et al. (2013): Dopravní sektorové strategie 2. Fáze (souhrnný dokument). Ministerstvo dopravy, Praha, 305 pp. Retrieved October 15, 2013 from http://www.dopravnistrategie.cz/.

WIĘCKOWSKI, M., MICHNIAK, D., BEDNAREK-SZCEPAŃSKA, M., CHRENKA, B., IRA, V., KOMORNICKI, T., ROSIK, P., STĘPNIAK, M., SZÉKELY, V., SLESZYŃSKI, P., ŚWIĄTEK, D., WIŚNIEWSKI, R. (2012): Pol'sko-slovenské pohraničie z hl'adiska dopravnej dostupnosti a rozvoja cestovného ruchu. Varšava: Instytut Geografii i Przestrzennego Zagospodarowania Polska Akademia Nauk; Bratislava : Geografický ústav Slovenskej akadémie vied. 283 p. 